\title{
The Influence of pH of Extracting Water on the Composition of Seaweed Extracts and Their Beneficial Properties on Lepidium sativum
}

\author{
Katarzyna Godlewska, Izabela Michalak, Lukasz Tuhy, and Katarzyna Chojnacka \\ Department of Advanced Material Technologies, Faculty of Chemistry, Wrocław University of Science and Technology, \\ Smoluchowskiego 25, 50-372 Wrocław, Poland \\ Correspondence should be addressed to Izabela Michalak; izabela.michalak@pwr.edu.pl
}

Received 27 December 2016; Accepted 15 March 2017; Published 5 April 2017

Academic Editor: Muhammad Faisal

Copyright (C) 2017 Katarzyna Godlewska et al. This is an open access article distributed under the Creative Commons Attribution License, which permits unrestricted use, distribution, and reproduction in any medium, provided the original work is properly cited.

\begin{abstract}
Baltic seaweeds were used to obtain aqueous extracts (E) through changing initial $\mathrm{pH}$ of deionised water added to algal biomass $\left(\mathrm{EpH} 3 \cdot \mathrm{H}_{2} \mathrm{O}, \mathrm{EpH} 7 \cdot \mathrm{H}_{2} \mathrm{O}\right.$, and EpH10 $\left.\cdot \mathrm{H}_{2} \mathrm{O}\right)$ and through changing $\mathrm{pH}$ of the mixture of algae and deionised water $(\mathrm{EpH} 3$, EpH7, and EpH10). Algal extracts were characterized in terms of the concentration of polyphenols and micro- and macroelements. The highest concentration of polyphenols was determined in extract EpH3 and the lowest in extract EpH10 $\cdot \mathrm{H}_{2} \mathrm{O}$. It was found that the obtained extracts had similar concentrations of elements (except EpH3). The phytotoxicity of algal extracts $(0.5,2.5$, and $10 \%)$ was examined in the germination tests on Lepidium sativum. No phytotoxic effects were observed. It was found that they had beneficial effects on the cultivated plants (length and weight). The best biostimulant effect was observed in the groups treated with EpH3 (2.5\%), EpH7 (2.5\%), and EpH7 (10\%). The dry weight of plants was similar in all the groups. Algal extract also improved the multielemental composition of plant. The greatest concentration of total chlorophyll in plants was obtained by using extract EpH10. $\mathrm{H}_{2} \mathrm{O}, 0.5 \%$. These results proved that algal extracts have high potential to be applied in cultivation of plants.
\end{abstract}

\section{Introduction}

Algae are mostly autotrophic organisms living in the aquatic or at least damp environment [1]. Their sizes range from a few micrometers (microalgae) up to several meters in case of macroalgae. Algae, due to the richness of organic and inorganic compounds, became the subject of many studies and were found to be useful in many industries, from cosmetics, through food to plant cultivation and animal breeding [2]. Among the most popular macroalgae, constituting a great source of biologically active compounds, green, red, and brown algae should be listed.

Bioactive compounds, naturally occurring in algae, were also found in extracts obtained from these organisms [3]. Algal extracts could be produced by either physical or chemical methods. Among all methods used for the algal extracts preparation (enzymatic extraction [4], microwave assisted extraction [5], and supercritical $\mathrm{CO}_{2}$ extraction [6]), extraction with the use of traditional solvents such as water, alcohol, inorganic acids, and bases seems to be the most popular. Algae extracts contain a large number of organic and mineral compounds (micro- and macronutrients). They are particularly rich in phytohormones (indoleacetic acids (IAA), commonly known as auxins, gibberellic acids, cytokinins, abscisic acids (ABA), and ethylene), complex organic compounds, vitamins, simple and complex sugars (polysaccharides like alginates, laminaria, and carrageenans), enzymes, $\mathrm{N}$-containing compounds like betaines, proteins, and amino acids and sterols [7]. Among them, plant hormones-phytohormones-which are synthesized in the plant to regulate a multitude of essential cellular and tissue functions including stem elongation, root initiation, and tissue differentiation [8], play a significant role. The application of sequential extraction with solvent such as hot sodium oxalate, hot water, and $\mathrm{KOH}$ contributes to the extraction of biologically active compound (e.g., polysaccharides) from 
Ulva rigida [9]. Chemical components of algal extracts that affect plant growth were extensively described in many review papers $[10,11]$.

The positive effect of algal extracts on the plants growth and development was confirmed in many scientific publications. Increased chlorophyll content in tomatoes leaves and cucumbers, for both foliar and soil application was observed in comparison with control group. The main factor influencing the differences in chlorophyll content was high content of betaine in extracts from Ascophyllum nodosum [12]. It was also proved that the application of seaweed extracts in viticulture improved uptake of copper by plants [13]. The use of an extract from Kappaphycus alvarezii significantly improved the yield and nutrient uptake (primarily N, P, K, and S) for soybean [14] while the application of Ascophyllum nodosum extract in small concentrations had a positive effect on the radish development [15]. Algal extracts also improve resistance to stress factors, both biotic and abiotic [11].

In literature, a lot of attention is put on the description of the algal extracts impact on organic compounds composition, while there is little data including the elemental composition of preparations, which can be very important from the point of view of growing plants. The aim of the present work was to investigate the influence of different $\mathrm{pH}$ on chemical composition of seaweed extracts and to examine utilitarian properties of obtained preparations in laboratory tests on Lepidium sativum.

\section{Materials and Methods}

2.1. Chemicals. Sodium carbonate, ethanol, and methanol were purchased from POCH SA (Gliwice, Poland). FolinCiocalteu's phenol reagent, gallic acid, and nitric acid, 69\%, were purchased from Merck KGaA (Darmstadt, Germany). All the reagents were of analytical grade.

2.2. Collection of Algae. The mixture of seaweeds, Polysiphonia, Ulva, and Cladophora, was collected directly from the water of Baltic Sea (Sopot, Poland) in August 2013. The biomass was rinsed with water in order to purify it from salt and partially from sand. In the next step, the impurities (e.g., shingles, sand, sea shells, and pieces of wood) were separated and the biomass was dried to $15 \%$ of moisture and ground to obtain particle size $<0.3 \mathrm{~mm}$ (Wilk et al., 2014).

2.3. Extract Production. Extraction processes were made according to the modified procedures described by Sharma et al. [16]. To set appropriate $\mathrm{pH}$ (using pH meter Seven Multi; Mettler Toledo; Greifensee, Switzerland), hydrochloric acid $(0.1 \mathrm{~mol} / \mathrm{L})$ and sodium hydroxide $(0.1 \mathrm{~mol} / \mathrm{L})$ were used. In the first method, the dried and milled algal biomass ( $50 \mathrm{~g}$ ) was added to $150 \mathrm{~mL}$ of deionised water with $\mathrm{pH} 3,7$, and 10, respectively (marked as extract (E) EpH3 $\cdot \mathrm{H}_{2} \mathrm{O}, \mathrm{EpH} 7 \cdot \mathrm{H}_{2} \mathrm{O}$, and $\mathrm{EpH} 10 \cdot \mathrm{H}_{2} \mathrm{O}$ ). In the second method, $50 \mathrm{~g}$ of the dried and milled algal biomass was added to $150 \mathrm{~mL}$ of deionised water and then $\mathrm{pH}$ of the mixture was set to values 3,7 , and 10, respectively (marked as extract EpH3, EpH7, and EpH10). Then all flasks were shaken for 30 minutes, $150 \mathrm{rpm}$ at $25^{\circ} \mathrm{C}$
(IKA KS 260 compact flat orbital shaker, Staufen, Germany). In the next step, each of six samples was centrifuged at $4250 \mathrm{rpm}$ for 5 minutes (Heraeus Megafuge 40, rotor TX-750, Thermo Scientific, Waltham, MA, USA) and filtered using Whatman No. 1 filter paper. The obtained supernatant was taken as a $100 \%$ algal liquid extract.

2.4. Characteristics of Algal Extract. The characteristics of algal extracts were made according to the procedures described by Michalak et al. [17].

2.4.1. Multielemental Composition. The content of elements in seaweeds, algal extracts, and cultivated plants was determined by ICP-OES iCAP 6500 Duo (Thermo Scientific, Waltham, MA, USA). The samples of seaweeds and garden cress $(0.5 \mathrm{~g})$ were purified from organic matter with nitric acid $(69 \% ; 5 \mathrm{~mL})$ in Teflon bombs in a microwave oven Milestone Start D (Milestone S.r.l., Sorisole, Italy) and diluted with redemineralized water (Millipore Simplicity, Darmstadt, Germany) to $50 \mathrm{~g}$. The samples were analyzed in three repetitions [17].

2.4.2. Phenolic Compounds in the Algal Extracts. The concentration of phenolic compounds in obtained $100 \%$ algal extracts was determined according to the modified procedure described by Sim et al. [18]. The calibration curve was made with concentrations of gallic acid ranging from 25 to $1000 \mathrm{mg} / \mathrm{L}$. Each concentration of gallic acid $(0.1 \mathrm{~mL})$ was mixed with deionised water $(7.9 \mathrm{~mL})$ and subsequently the Folin-Ciocalteu's phenol reagent $(0.5 \mathrm{~mL})$ was added to the samples. After 3 minutes, $1.5 \mathrm{~mL}$ of saturated sodium carbonate solution was added to the mixture and afterwards all mixtures were incubated for 30 minutes at $40^{\circ} \mathrm{C}$. The blank contained only methanol. The absorbance $(765 \mathrm{~nm})$ was measured using a spectrophotometer, Varian Cary 50 Conc. Instrument (Victoria, Australia). The gallic acid calibration plot was obtained by plotting the absorbance versus the gallic acid concentration $(\mathrm{mg} / \mathrm{L})[17,18]$.

\subsection{Utilitarian Properties of Algal Extracts}

2.5.1. Germination Tests: Petri Dish Tests. The phytotoxicity of the algal extracts was evaluated in the germination tests on garden cress (Lepidium sativum). The effect of different concentrations $(0.5,2.5$, and $10 \%)$ of extracts on the growth of plants was tested. The dilutions were determined in previous work [19]. Experiments were conducted on Petri dishes, in 3 replicates for each group in standardized conditions using Jacobsen apparatus (Laborset, Lodz, Poland) according to the international norm (International Rules for Seed Testing, 2011-International Seed Testing Association (Bassersdorf, Switzerland)). On each Petri dish (diameter $85 \mathrm{~mm}$ ), 50 seeds were placed on the universal soil ( $15 \mathrm{~g}$ ) from "Lasland (C)" (Lasland sp. z o.o. Grądy, Poland). After stratification $\left(5^{\circ} \mathrm{C}\right.$, 3 days), each dish was watered with algal extract $(5 \mathrm{~mL})$, whereas control group (C) was watered with distilled water $(5 \mathrm{~mL})$. After three days, all dishes were treated with the same doses of extracts or water. After seven days, cultivated 
plants were collected. Measurements of shoot length were carried out. The plant biomass was dried at temperature of $50^{\circ} \mathrm{C}$ (dryer Wamed SUP-30, Warsaw, Poland) and weighed (results expressed as a dry weight (d.w.)) [17].

\subsubsection{Chlorophyll Concentration in Extract from Garden Cress.} The total chlorophyll (Total Chl), chlorophyll $a(\mathrm{Chl}(a))$, and chlorophyll $b(\mathrm{Chl}(b))$ in the fresh aerial parts of cultivated garden cress were determined by UV-VIS spectrophotometer (Varian Cary 50 Conc. Instrument, Victoria, Australia) at the following wavelengths: $\lambda=663$ and $645 \mathrm{~nm}$. Extractions were made in acetone $[17,20]$.

2.6. Statistical Analysis. The results were elaborated statistically by Statistica ver. 12 (StatSoft Polska Sp. z o.o., Kraków, Poland). Normality of distribution of experimental results was assessed by Shapiro-Wilk test. For normal distribution, homogeneity of variance was checked by means of the BrownForsythe test. For more than two groups, the differences were investigated with the (RIR) Tukey test, which compares all pairs of means following one-way ANOVA. Results were considered significantly different when $p<0.05$. If the distribution of the results was other than normal, the KruskalWallis test was used.

\section{Results and Discussion}

\subsection{Characteristics of the Algal Extract}

3.1.1. Multielemental Composition of Algal Extracts. The appropriate fertilization enables obtaining quantitative and qualitative crops. Plants require at least 14 mineral elements, which include macroelements (nitrogen, phosphorus, potassium, calcium, magnesium, and sulphur), but also essential microelements (boron, iron, manganese, copper, zinc, nickel, and molybdenum). Deficiency of any of these mineral elements reduces plant growth and crop yields [2123]. Therefore, algal extracts were examined whether they could be a source of valuable micro- and macroelements for plants. In Table 1, the elemental composition of the produced algal extracts is presented. It could be noticed that toxic elements were extracted from the raw algal biomass in low amounts in all examined variants. Extracts obtained through the changing of the value of water $\mathrm{pH}$ were similar in terms of the elemental composition. The highest extraction of elements was found to be for $\mathrm{EpH} 7 \cdot \mathrm{H}_{2} \mathrm{O}$. It contained the highest concentration of $\mathrm{Ca}, \mathrm{Mg}, \mathrm{Na}$, and $\mathrm{S}$ among macroelements and $\mathrm{Cu}, \mathrm{Mn}$, and $\mathrm{Zn}$ among microelements. The greatest concentration of $\mathrm{P}$ was noticed in $\mathrm{EpH} 3 \cdot \mathrm{H}_{2} \mathrm{O}$. From this group, extraction in the group $\mathrm{pH} 10 \cdot \mathrm{H}_{2} \mathrm{O}$ appeared to be the least effective. In the case of the second extraction method it could be seen that low $\mathrm{pH}$ of water solution promoted the extraction of elements from the algal biomass. $\mathrm{EpH} 3$, in comparison with the other extracts, was especially rich in $\mathrm{Ca}, \mathrm{Mg}, \mathrm{Na}$, and $\mathrm{P}$ and $\mathrm{B}, \mathrm{Fe}, \mathrm{Mn}, \mathrm{Ni}, \mathrm{Si}$, and $\mathrm{Zn}$. An extract which can be recommended for further study is EpH3. Table 1 shows also the elemental characteristics of algal extracts obtained by other extraction techniques using water as a solvent. The multielemental composition of extracts obtained by Microwave-Assisted Extraction (MAE) proved that temperature played a significant role in the extraction of elements; at lower temperature, lower amounts of elements were extracted. The extract obtained at $60^{\circ} \mathrm{C}$ was the most favorable in contrast to these produced at 25 and $40^{\circ} \mathrm{C}$; the concentration of $\mathrm{Fe}$ and $\mathrm{Si}$ was four times higher and $\mathrm{Zn}$ two times higher than in the extract obtained at $25^{\circ} \mathrm{C}$ [17]. The extract obtained by boiling of algal biomass in water was especially rich in $\mathrm{P}, \mathrm{S}$, and $\mathrm{B}$; on the other hand the extract obtained by soaking in water contained a great concentration of $\mathrm{Ca}, \mathrm{Mg}$, and $\mathrm{Fe}$ [19]. These essential mineral elements could be supplied to crops with algal extracts to achieve greater yields and also to increase their content in edible parts.

3.1.2. Polyphenols in Algal Extracts. Polyphenols are prevalent class of plant secondary metabolites and have received increasing attention in recent years due to their bioactive functions. These compounds may play different roles in human life and plant biology, such as antioxidant and protective agents against UV light, contributors to the taste of food, drink, and pharmaceuticals, defensiveness against herbivores and pathogens, and contributors to plant pigmentation but also as phytoalexins, antifeedants, and attractants for pollinators [24, 25]. Most of polyphenols present in plants are soluble in polar solvents and the extraction yields depend on extraction conditions. The low $\mathrm{pH}$ value of the extraction solution can prevent the oxidation of phenolics [26]. Figure 1 presents the total phenolic concentration $[\mathrm{mg} / \mathrm{L}$ of gallic acid equivalents (GAEs) calculated from the equation: $y=$ $0.0003 \cdot x\left(R^{2}=0.9959\right)$, where $y$ is absorbance and $x$ is concentration] in algal extracts. Generally, obtained extracts were similar in terms of the total phenolic concentration except EpH3 which was characterized by the highest concentration of these compounds $(1077 \mathrm{mg} / \mathrm{L})$. The results obtained by Horincar et al. [27] proved that water was the best solution to extract polyphenols in contrast to acetone, methanol, ethanol, and hexane. Water extract of Cladophora vagabunda contained $212 \mathrm{mg}$ equivalent GAE/100 g of dry alga powder when methanolic extract contained $110 \mathrm{mg} / 100 \mathrm{~g}$. In case of Enteromorpha intestinalis, its water extract had $146 \mathrm{mg} / 100 \mathrm{~g}$ while methanolic extract was only $75.5 \mathrm{mg} / 100 \mathrm{~g}$ [27]. Contrary data were presented by Narasimhan et al. [28] who determined polyphenol content in green seaweed samples, Enteromorpha antenna and Enteromorpha linza, extracted with different solvents such as chloroform, ethyl acetate, acetone, butanol, methanol, ethanol, and water. The total phenolic content was the highest for methanolic extract of Enteromorpha antenna (1.82 $\pm 0.05 \mathrm{GAE} \mathrm{mg} / \mathrm{g})$ and E. linza $(0.912 \pm 0.032 \mathrm{GAE} \mathrm{mg} / \mathrm{g})$. Ganesan et al. [29] prepared seaweed extracts by adding $20 \mathrm{~g}$ of algal sample (Enteromorpha compressa, E. linza, and E. tubulosa) to $200 \mathrm{~mL}$ of individual solvent (ethyl acetate, methanol, propanol, acetone, and water) for $6 \mathrm{~h}$ at room temperature using a Soxhlet extractor. The maximum total phenol content (\%) was observed in the extract of acetone $(11.63 \pm 0.39)$, methanol $(3.45 \pm 0.18)$, and acetone $(6.30 \pm 0.06)$ for E. compressa, E. linza, and E. tubulosa, respectively. The lowest total phenol content was 


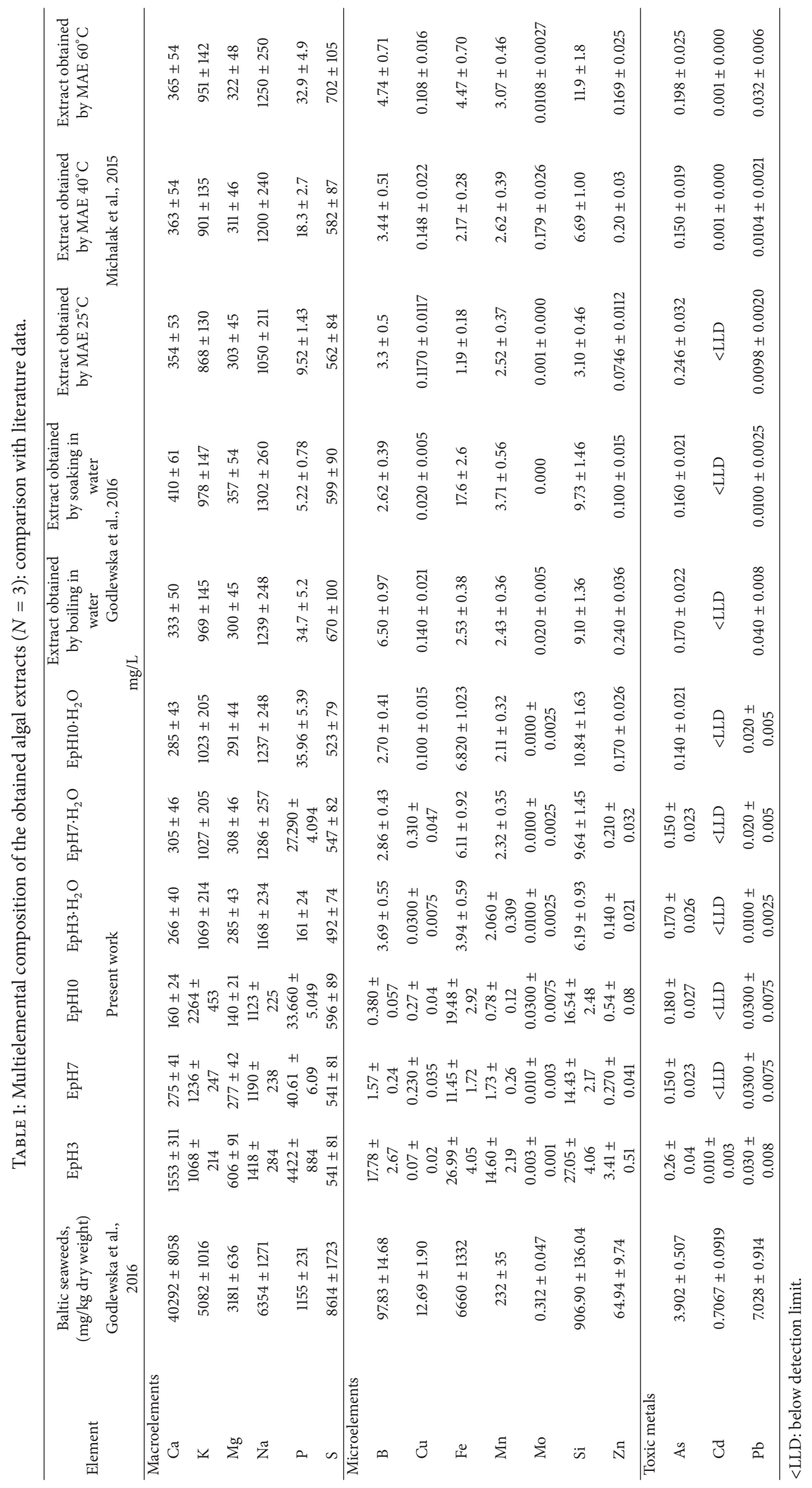




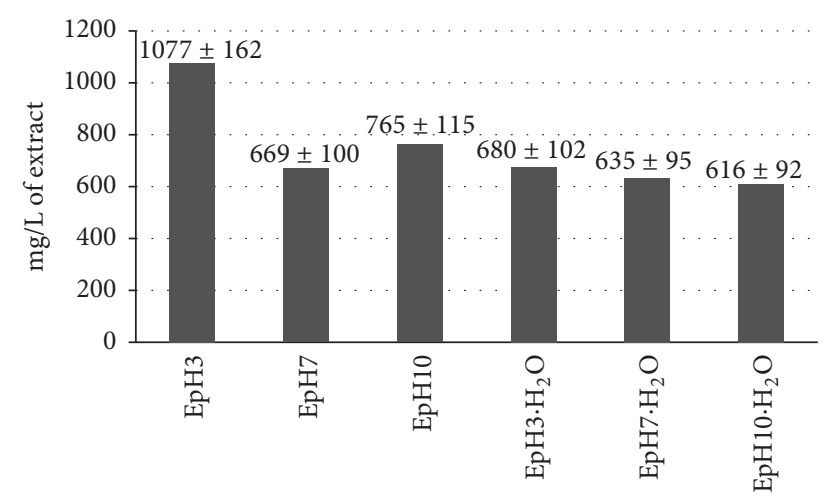

Algal extract

FIGURE 1: Total phenolic concentration $(N=3)$ in the obtained algal extracts.

observed in the water extract of E. compressa $(2.98 \pm 0.39)$ and $E$. linza $(1.33 \pm 0.08)$, while ethyl acetate extract revealed the lowest phenols content in E. tubulosa (1.21 \pm 0.05$)$ [29]. Cho et al. [30] in their study used $50 \mathrm{~g}$ of milled sample of Enteromorpha prolifera and $500 \mathrm{~mL}$ of $95 \%$ ethanol to prepare algal extracts. Then the crude extract was dissolved in distilled water and then partitioned sequentially in three different solvents, namely, $n$-hexane, chloroform, and ethyl acetate. The total phenolic contents of the crude extract and solvent-partitioned fractions ranged from 46.2 to $80.4 \mathrm{mg}$ GAE/g [30]. The variation of total phenol content between the Chlorophyta species might be due to extrinsic factors (herbivory pressure, irradiance, depth, salinity, nutrients, etc.) and intrinsic agents (type, age, and reproductive stage) [29].

3.2. Utilitarian Properties of Algal Extracts. Side effects of synthetic fertilizers on the environment stimulated the use of new natural sources of biostimulants and soil conditioners [31]. The application of seaweed extracts in plant cultivation can improve plant growth, yield, nutrient uptake, and resistance to biotic and abiotic stress and enhance postharvest shelf-life of perishable products [11, 31, 32]. They show activity at low concentrations (1:1000 dilution) [11]. Algal compounds affect cellular metabolism in treated plants due to the presence of macro- and microelement nutrients, amino acids, vitamins, cytokinins, auxins and abscisic acid(ABA-) like growth substances. Seaweed products are easy to apply and relatively cheap (every year about 15 million metric tonnes are generated) [31].

3.2.1. Total Height of the Cultivated Garden Cress. The height of plants (20 plants from each repetition, $N=3$ ) was determined for all the obtained extracts tested in three dilutions $(0.5,2.5$, and $10 \%)$. Algal products showed varying degree of stimulant effect on the plants growth (Table 2). The control group was treated with water ( $\mathrm{pH}$ 7.39). Generally, the plant height increased with increasing concentration of extracts. The best results were observed in the groups treated with extracts obtained by changing $\mathrm{pH}$ of the mixture of algae and water. The application of EpH3 2.5\%, EpH7 $10 \%$, and EpH7 2.5\% influenced the plants height, which was $26.5,25.4$, and $25.0 \%$ longer than in the control group, respectively. The use of extracts obtained by changing $\mathrm{pH}$ of water resulted in the lowest biostimulant effect. In the groups EpH7 $\cdot \mathrm{H}_{2} \mathrm{O} 0.5 \%>\mathrm{EpH} 10 \cdot \mathrm{H}_{2} \mathrm{O} 0.5 \%>\mathrm{EpH} 7 \cdot \mathrm{H}_{2} \mathrm{O}$ $2.5 \%>\mathrm{EpH} 7 \cdot \mathrm{H}_{2} \mathrm{O} 10 \%$ plants were shorter than in the control group, respectively, by $9.3>7.6>1.3>0.93 \%$. In order to verify the statistically significant differences (for $p<0.05$ ) between the tested groups, two analyses, using STATISTICA software, were performed. In the first comparison, between the control group and groups treated with extracts obtained by changing $\mathrm{pH}$ of mixture of water and algae, the statistically significant differences were found between the control and all other groups and between EpH3 2.5\% and EpH10 0.5\%. The data distribution was nonnormal; therefore the KruskalWallis test was chosen. In the second comparison, between the control group and preparations received by changing $\mathrm{pH}$ of water used for the extraction process, the statistically significant differences were found between $\mathrm{EpH} 3 \cdot \mathrm{H}_{2} \mathrm{O} 2.5 \%$ and $\mathrm{EpH} 7 \cdot \mathrm{H}_{2} \mathrm{O} 0.5 \%$, EpH7. $\mathrm{H}_{2} \mathrm{O} 0.5 \%$ and $\mathrm{EpH} 3 \cdot \mathrm{H}_{2} \mathrm{O} 10 \%$, $\mathrm{EpH} 10 \cdot \mathrm{H}_{2} \mathrm{O} 2.5 \%$ and EpH7 $\cdot \mathrm{H}_{2} \mathrm{O} 0.5 \%, \mathrm{EpH} 10 \cdot \mathrm{H}_{2} \mathrm{O} 10 \%$ and $\mathrm{EpH} \cdot \cdot \mathrm{H}_{2} \mathrm{O} 0.5 \%$, and EpH10 $\cdot \mathrm{H}_{2} \mathrm{O} 10 \%$ and $\mathrm{EpH} 10 \cdot \mathrm{H}_{2} \mathrm{O} 0.5 \%$. The distributions were normal; therefore Tukey test was used.

In the literature, several methods are used for the production of aqueous algal extracts. In the work of Fakihi Kachkach et al. [33], extracts were produced from dried biomass of Ulva rigida that was heated with distilled water in a ratio of $10: 100(\mathrm{w} / \mathrm{v})$ for 2 minutes. Different concentrations of extracts $(0.5,1,2$, and $4 \mathrm{mg}$ of dried seaweeds per $\mathrm{mL}$ of distilled water) were investigated in terms of growth of garden cress. Results showed that all extracts significantly affected growth of roots and stems of L. sativum. The highest stimulant effect was observed in the group treated with $1 \mathrm{mg} / \mathrm{mL}$, whereas the concentration $4 \mathrm{mg} / \mathrm{mL}$ showed lower stimulation of roots and stems growth. Latique et al. [34] investigated the effect of Ulva lactuca extract (obtained by boiling one kilogram of fresh seaweed with a liter of distilled water for one hour) on the growth of bean plants (Phaseolus vulgaris L.). Seaweed extracts were applied as a foliar spray at different concentrations: $6,12.5,25,50$, and 75\%. Two concentrations, 25 and 50\%, provided the significant effects on plant growth and the maximum effect was found in group treated with $25 \%$ extract $(44.7 \%$ longer than in the control group without seaweed extract). In the paper of Osman and Salem [35], the effect of foliar applications of different concentrations of seaweed extract of Ulva lactuca on sunflower (Helianthus annuus L.) was presented. Authors applied two concentrations 0.4 and $0.6 \% \mathrm{w} / \mathrm{v}, 3$ times: first one at the seedling stage (20 days after sowing), the second at the flowering stage (40 days after sowing), and the third one before yield stage (70 days after sowing). Seaweed extracts significantly increased plant height when compared to the control group without algal extract. The highest sunflower plants were recorded in the group treated with $0.4 \%$ U. lactuca (37.3\% higher).

3.2.2. Weight of the Cultivated Plants. The results of the research showed that the dry weight of Lepidium sativum 
TABLE 2: Total height of the cultivated garden cress in the experimental groups.

\begin{tabular}{|c|c|}
\hline Extract & $\begin{array}{c}\text { Average height } \\
\bar{x}(\mathrm{~cm}) \pm \mathrm{SD} \\
(N=3)\end{array}$ \\
\hline Control & $5.36 \pm 0.59$ \\
\hline ЕpH3 0.5\% & $6.45 \pm 0.44$ \\
\hline ЕpH3 2.5\% & $6.78 \pm 0.40^{\mathrm{a}}$ \\
\hline EpH3 10\% & $6.64 \pm 0.51$ \\
\hline EpH7 0.5\% & $6.35 \pm 0.70$ \\
\hline EpH7 2.5\% & $6.70 \pm 0.67$ \\
\hline EpH7 10\% & $6.72 \pm 0.64$ \\
\hline EpH10 0.5\% & $6.30 \pm 0.61^{\mathrm{a}}$ \\
\hline EpH10 2.5\% & $6.61 \pm 0.52$ \\
\hline EpH10 10\% & $6.67 \pm 0.63$ \\
\hline $\mathrm{EpH} 3 \cdot \mathrm{H}_{2} \mathrm{O} 0.5 \%$ & $5.50 \pm 0.76$ \\
\hline $\mathrm{EpH} 3 \cdot \mathrm{H}_{2} \mathrm{O} 2.5 \%$ & $5.57 \pm 0.71^{\mathrm{a}}$ \\
\hline EpH3. $\mathrm{H}_{2} \mathrm{O} 10 \%$ & $5.56 \pm 0.85^{\mathrm{a}}$ \\
\hline $\mathrm{EpH} 7 \cdot \mathrm{H}_{2} \mathrm{O} 0.5 \%$ & $4.86 \pm 0.79^{\mathrm{a}}$ \\
\hline $\mathrm{EpH} 7 \cdot \mathrm{H}_{2} \mathrm{O} 2.5 \%$ & $5.29 \pm 0.64$ \\
\hline $\mathrm{EpH} \cdot \cdot \mathrm{H}_{2} \mathrm{O} 10 \%$ & $5.31 \pm 1.03$ \\
\hline $\mathrm{EpH} 10 \cdot \mathrm{H}_{2} \mathrm{O} 0.5 \%$ & $4.95 \pm 1.04^{\mathrm{a}}$ \\
\hline $\mathrm{EpH} 10 \cdot \mathrm{H}_{2} \mathrm{O} 2.5 \%$ & $5.63 \pm 0.79^{\mathrm{a}}$ \\
\hline $\mathrm{EpH} 10 \cdot \mathrm{H}_{2} \mathrm{O} 10 \%$ & $5.64 \pm 0.96^{\mathrm{a}}$ \\
\hline
\end{tabular}

${ }^{a}$ Statistically significant differences $(p<0.05)$.

was similar in all the groups, taking into account all extracts and dilutions (Table 3). It could be noticed that the highest dry weight was in the groups treated with EpH10 2.5\% (16.4\% heavier than in the control) and EpH7 2.5\% (12.9\% heavier). Extract obtained with water with $\mathrm{pH} 10$ applied at a concentration $10 \%$ emerged to be the least effective (25.9\% lighter). Osman and Salem [35] showed that very low concentration (0.4 and $0.6 \%$ ) of U. lactuca extracts promoted dry weight of sunflower. In the group treated with extract at concentration $0.6 \%$, plants were heavier by about $87.5 \%$ than in the control. In the work of Khairy et al. [36], the seaweed extracts were prepared by soaking overnight one kilogram of Ulva lactuca and Enteromorpha compressa in a litre of distilled water. The filtrate was used to prepare different concentrations of algal products $(5 \%, 10 \%$, and $15 \%)$. Four foliar applications of each concentration were applied at $30,51,72$, and 93 days from sowing. The algal extracts stimulated the crop yield of broad bean (Vicia faba) as the total number of seeds and their weight per plot. Where the total number of seeds was 164 per plot for control, it was 266 $(394.4 \mathrm{~kg}$ ) by the application of $10 \%$ extract concentration of E. intestinalis and $267(423.6 \mathrm{~kg})$ for U. lactuca.

\subsubsection{Multielemental Composition of the Cultivated Garden} Cress. Iron, zinc, selenium, calcium, magnesium, and copper deficiencies are common in many countries. The main causes of this situation are crop production in areas with low mineral phytoavailability and consumption of scarce amount of fish
TABLE 3: The dry weight of cultivated garden cress in the experimental groups.

\begin{tabular}{|c|c|}
\hline Extract & $\begin{array}{l}\text { Average dry weight } \\
\bar{x}(\mathrm{~g}) \pm \mathrm{SD}(N=3)\end{array}$ \\
\hline Control & $0.0739 \pm 0.0033$ \\
\hline ЕpH3 0.5\% & $0.0773 \pm 0.0015$ \\
\hline ЕpH3 2.5\% & $0.0788 \pm 0.0050$ \\
\hline EpH3 10\% & $0.0800 \pm 0.0031$ \\
\hline EpH7 0.5\% & $0.0778 \pm 0.0030$ \\
\hline EpH7 2.5\% & $0.0834 \pm 0.0010$ \\
\hline EpH7 10\% & $0.0778 \pm 0.0015$ \\
\hline EpH10 0.5\% & $0.0782 \pm 0.0054$ \\
\hline EpH10 2.5\% & $0.0860 \pm 0.0009$ \\
\hline EpH10 10\% & $0.0826 \pm 0.0040$ \\
\hline EpH3 $\cdot \mathrm{H}_{2} \mathrm{O} 0.5 \%$ & $0.0679 \pm 0.0028$ \\
\hline $\mathrm{EpH} 3 \cdot \mathrm{H}_{2} \mathrm{O} 2.5 \%$ & $0.0665 \pm 0.0012$ \\
\hline EpH3. $\mathrm{H}_{2} \mathrm{O} 10 \%$ & $0.0697 \pm 0.0015$ \\
\hline $\mathrm{EpH} 7 \cdot \mathrm{H}_{2} \mathrm{O} 0.5 \%$ & $0.0615 \pm 0.0009$ \\
\hline $\mathrm{EpH} 7 \cdot \mathrm{H}_{2} \mathrm{O} 2.5 \%$ & $0.0606 \pm 0.0016$ \\
\hline $\mathrm{EpH} 7 \cdot \mathrm{H}_{2} \mathrm{O} 10 \%$ & $0.0612 \pm 0.0005$ \\
\hline $\mathrm{EpH} 10 \cdot \mathrm{H}_{2} \mathrm{O} 0.5 \%$ & $0.0554 \pm 0.0006$ \\
\hline $\mathrm{EpH} 10 \cdot \mathrm{H}_{2} \mathrm{O} 2.5 \%$ & $0.0596 \pm 0.0023$ \\
\hline EpH10· $\mathrm{H}_{2} \mathrm{O} 10 \%$ & $0.0547 \pm 0.0129$ \\
\hline
\end{tabular}

or animal products and crops with inherently low mineral contents [37]. Dietary diversification, supplementation, food fortification, and increasing mineral contents in edible crops could be used to combat dietary micronutrient deficiencies $[37,38]$. Perhaps, biofortification of staple food crops is the most feasible approach to lower the number of severely malnourished people and help to maintain improved nutritional status [38-40]. The present study proved that the application of seaweed extracts can increase the content of micro- and macroelements in plants (Tables 4 and 5). Algal extract, obtained with water with $\mathrm{pH} 10$, applied at the concentration $10 \%\left(\mathrm{pH} 10 \cdot \mathrm{H}_{2} \mathrm{O}(10 \%)\right)$ affected to the highest extent the content of macroelements in the cultivated garden cress; for example, plants contained about $78.5 \%$ more $\mathrm{Na}$, 36\% more $\mathrm{Mg}, 35 \%$ more $\mathrm{K}$, and $15 \%$ more Ca than plants in the control group. The highest amounts of $\mathrm{P}$ and $\mathrm{S}$ were in the group treated with $\mathrm{pH} 10 \cdot \mathrm{H}_{2} \mathrm{O}(0.5 \%)$ (23 and $39 \%$ more, resp.). In the case of microelements, the highest content of $\mathrm{B}$ was in the group treated with $\mathrm{EpH} 310 \%$ (273\% more), $\mathrm{Cu}$ in the group EpH10 $\cdot \mathrm{H}_{2} \mathrm{O} 0.5 \%$ (109\% more), $\mathrm{Si}$ in EpH7 $\cdot \mathrm{H}_{2} \mathrm{O}$ $2.5 \%$ (153\% more), $\mathrm{Zn}$ in EpH7 0.5\% (97\% more), $\mathrm{Mn}$ in $\mathrm{EpH} 3 \cdot \mathrm{H}_{2} \mathrm{O} 2.5 \%$ (76\% more), and Mo in groups EpH3. $\mathrm{H}_{2} \mathrm{O}$ $0.5 \%$ and $\mathrm{EpH} 3 \cdot \mathrm{H}_{2} \mathrm{O} 2.5 \%$ (94\%) compared to the control group. The cultivated Lepidium sativum contained mainly these elements, which occurred in the largest concentrations in the algal extract.

3.2.4. Chlorophyll Concentration in the Extract from Cultivated Cress. The concentration of total chlorophyll (Total Chl), $\mathrm{Chl}(a)$, and $\mathrm{Chl}(b)$ in extracts from the cultivated plants 


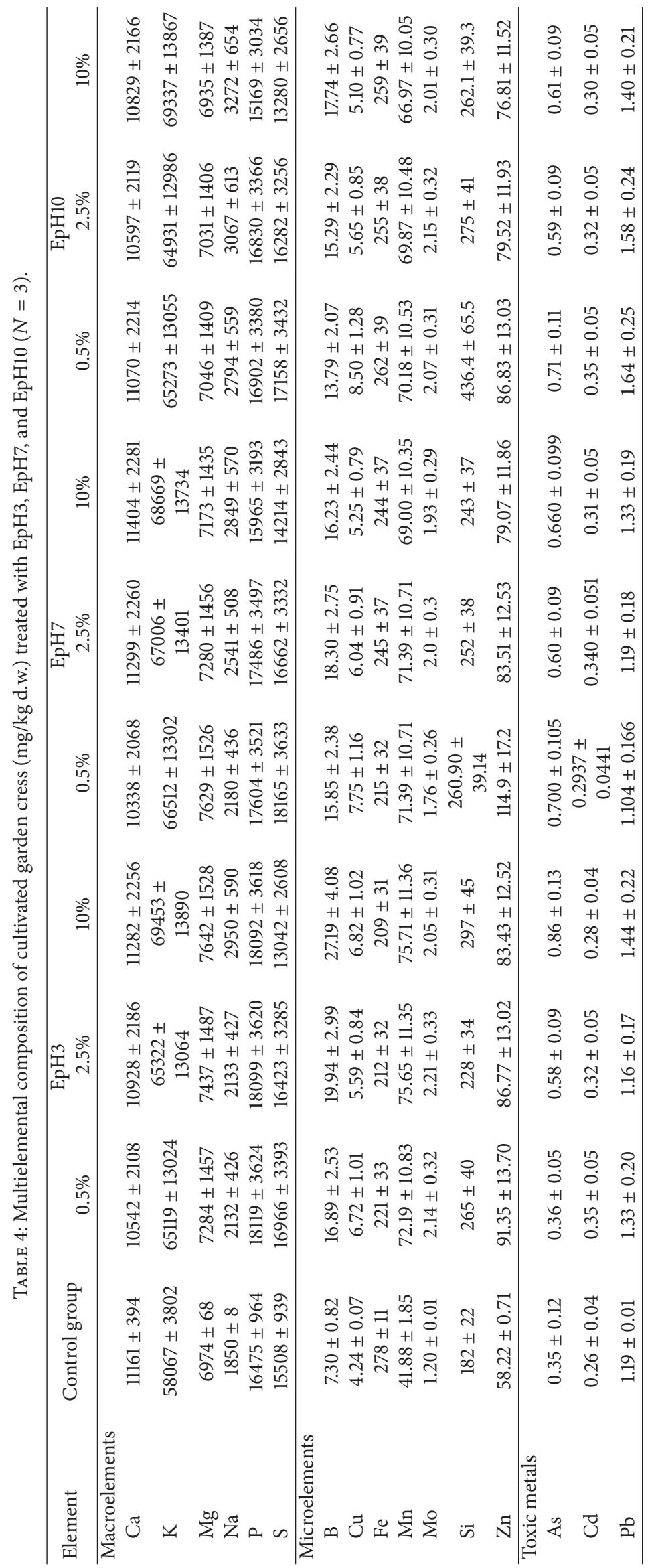




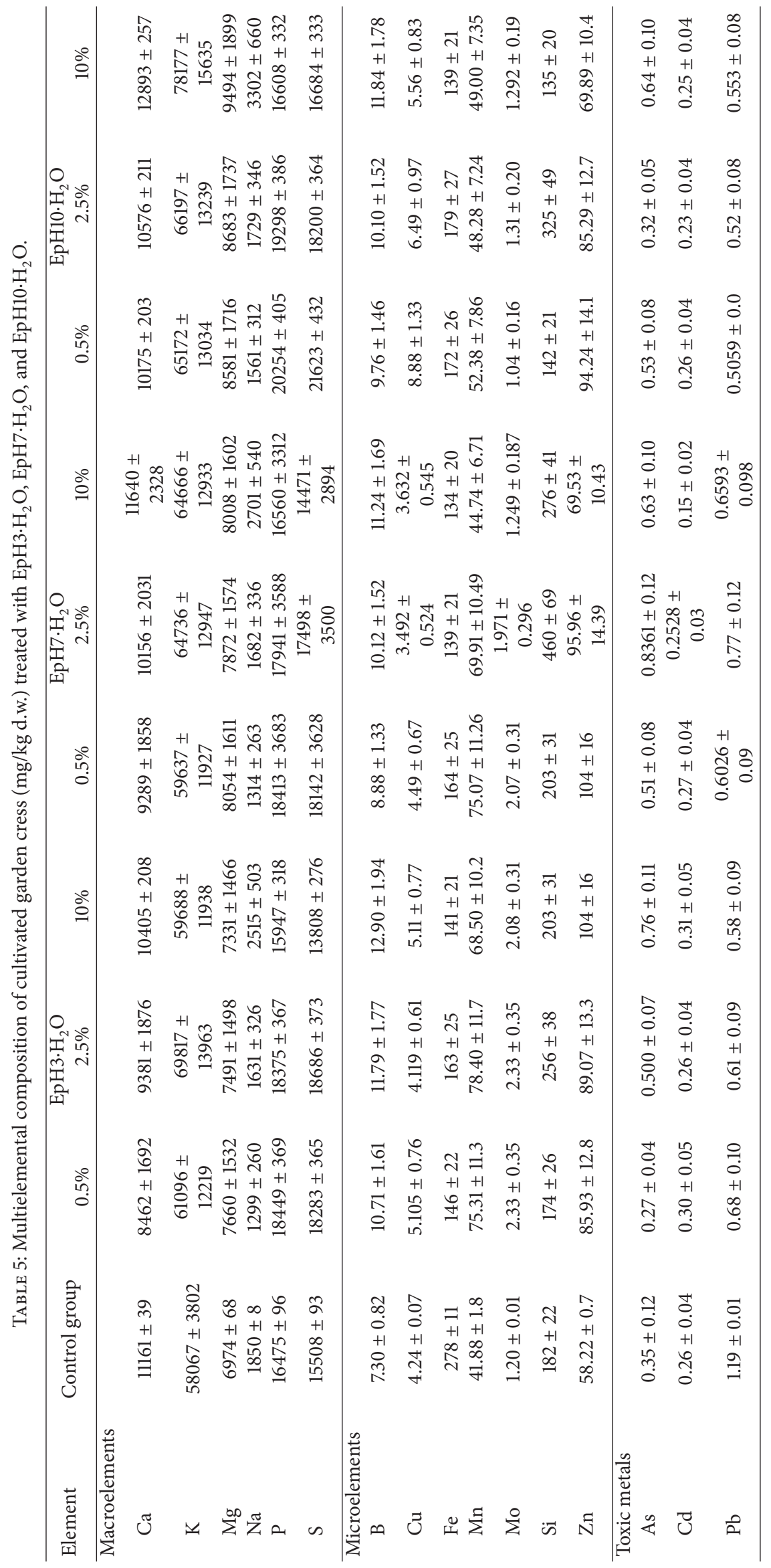


TABLE 6: Chlorophyll concentration in the extracts of cultivated garden cress $(\mathrm{mg} / \mathrm{L})(N=3)$.

\begin{tabular}{|c|c|c|c|}
\hline Sample & Concentration of chlorophyll $a$ & Concentration of chlorophyll $b$ & Total chlorophyll concentration \\
\hline Control & $15.53 \pm 2.33$ & $5.95 \pm 0.89$ & $21.48 \pm 3.22$ \\
\hline ЕpH3 0.5\% & $19.35 \pm 2.90$ & $6.79 \pm 1.02$ & $26.14 \pm 3.92$ \\
\hline ЕpH3 2.5\% & $20.26 \pm 3.04$ & $6.28 \pm 0.94$ & $26.54 \pm 3.98$ \\
\hline EpH3 10\% & $17.89 \pm 2.68$ & $6.11 \pm 0.92$ & $24.00 \pm 3.6$ \\
\hline EpH7 0.5\% & $18.92 \pm 2.84$ & $6.69 \pm 1.00$ & $25.60 \pm 3.84$ \\
\hline EpH7 2.5\% & $16.62 \pm 2.49$ & $5.76 \pm 0.86$ & $22.37 \pm 3.36$ \\
\hline EpH7 10\% & $22.79 \pm 3.42$ & $8.64 \pm 1.30$ & $31.43 \pm 4.71$ \\
\hline EpH10 0.5\% & $20.29 \pm 3.04$ & $7.12 \pm 1.07$ & $27.41 \pm 4.11$ \\
\hline EpH10 2.5\% & $17.81 \pm 2.67$ & $5.98 \pm 0.90$ & $23.78 \pm 3.57$ \\
\hline EpH10 10\% & $19.08 \pm 2.86$ & $6.62 \pm 0.99$ & $25.69 \pm 3.85$ \\
\hline $\mathrm{EpH} 3 \cdot \mathrm{H}_{2} \mathrm{O} 0.5 \%$ & $21.24 \pm 3.19$ & $7.90 \pm 1.19$ & $29.14 \pm 4.37$ \\
\hline $\mathrm{EpH} 3 \cdot \mathrm{H}_{2} \mathrm{O} 2.5 \%$ & $21.78 \pm 3.27$ & $8.84 \pm 1.33$ & $30.62 \pm 4.59$ \\
\hline $\mathrm{EpH} 3 \cdot \mathrm{H}_{2} \mathrm{O} 10 \%$ & $22.76 \pm 3.41$ & $8.50 \pm 1.28$ & $31.26 \pm 4.69$ \\
\hline $\mathrm{EpH} 7 \cdot \mathrm{H}_{2} \mathrm{O} 0.5 \%$ & $23.49 \pm 3.52$ & $9.04 \pm 1.36$ & $32.52 \pm 4.88$ \\
\hline $\mathrm{EpH} 7 \cdot \mathrm{H}_{2} \mathrm{O} 2.5 \%$ & $23.38 \pm 3.51$ & $8.31 \pm 1.25$ & $31.68 \pm 4.75$ \\
\hline $\mathrm{EpH} 7 \cdot \mathrm{H}_{2} \mathrm{O} 10 \%$ & $19.95 \pm 2.99$ & $7.09 \pm 1.06$ & $27.03 \pm 4.06$ \\
\hline $\mathrm{EpH} 10 \cdot \mathrm{H}_{2} \mathrm{O} 0.5 \%$ & $25.74 \pm 3.86$ & $10.13 \pm 1.52$ & $35.87 \pm 5.38$ \\
\hline $\mathrm{EpH} 10 \cdot \mathrm{H}_{2} \mathrm{O} 2.5 \%$ & $25.71 \pm 3.86$ & $8.84 \pm 1.33$ & $34.54 \pm 5.18$ \\
\hline EpH10· $\mathrm{H}_{2} \mathrm{O} 10 \%$ & $22.04 \pm 3.31$ & $7.65 \pm 1.15$ & $29.69 \pm 4.00$ \\
\hline
\end{tabular}

was determined from the following equations [20] and is presented in Table 6:

$$
\begin{aligned}
\text { Total Chl } & =8.02 \cdot \mathrm{A}(663)+20.2 \cdot \mathrm{A}(645) \\
C_{\mathrm{Chl}(a)} & =12.7 \cdot \mathrm{A}(663)-2.69 \cdot \mathrm{A}(645) \\
C_{\mathrm{Chl}(b)} & =22.9 \cdot \mathrm{A}(645)-4.68 \cdot \mathrm{A}(663) .
\end{aligned}
$$

In most cases, total chlorophyll concentration in extracts from Lepidium sativum in the experimental groups was higher than in the control group. Only in the group treated with EpH7 2.5\% the concentration of chlorophyll $b$ was $3.3 \%$ lower than in the control group. The highest concentration of chlorophyll $a$, chlorophyll $b$, and total chlorophyll in plant was in the group treated with $\mathrm{EpH} 10 \cdot \mathrm{H}_{2} \mathrm{O} 0.5 \%(65.8 \%$, $70.3 \%$, and $67.3 \%$ more than in the control group, resp.). These results proved that algal extracts increased plant productivity, resulting in increased chlorophyll content. Latique et al. [34] also reported that higher chlorophyll $a$ content was found for $25 \%$ Ulva rigida extract $(20.08 \mathrm{mg} / \mathrm{g}$ d.w.) when compared with the control plants $(4.4 \mathrm{mg} / \mathrm{g}$ d.w.). Osman and Salem [35] observed that foliar application of aqueous extract of Ulva lactuca significantly increased the chlorophyll content in sunflower. In the first stage (45 days from plantation), the highest $\operatorname{chl}(a)$ was detected in sunflower plant treated with $0.4 \%$ U. lactuca $(7.40 \mathrm{mg} / \mathrm{g})$, while the highest $\mathrm{chl}(b)$ was recorded in plant treated with $0.6 \%$ U. lactuca $(3.36 \mathrm{mg} / \mathrm{g})$. In the second stage ( 65 days from plantation), the highest chlorophyll $a$ and chlorophyll $b$ were detected in plant treated with $0.6 \%$ U. lactuca (6.28 and $2.61 \mathrm{mg} / \mathrm{g}$, resp.). Our previous study $[17,19]$ also proved that aqueous seaweed extracts can enhance plant chlorophyll content.

\section{Conclusions}

Polysiphonia, Ulva, and Cladophora derived seaweed extracts may be beneficial in increasing the growth parameters (plant height and weight) and chlorophyll content and enhancing nutrient uptake by plants. The application of algal products may deliver substantial economic and environmental benefits. Research will be continued to launch the product in the market (field test, development of the production technology, proposal of an installation, preliminary economic analysis, etc.).

\section{Conflicts of Interest}

The authors declare that they have no conflicts of interest.

\section{Acknowledgments}

This project is financed in the framework of grant entitled "Biologically Active Compounds in Extracts from Baltic Seaweeds" (no. 2012/05/D/ST5/03379) attributed to the National Science Centre in Poland and project supported by Wrocław Centre of Biotechnology, programme of the Leading National Research Centre (KNOW), for years 2014-2018 (print of the publication).

\section{References}

[1] A. A. Gatenby, S. M. Van der Vies, and D. Bradley, "Assembly in E. Coli of a functional multi-subunit ribulose bisphosphate carboxylase from a blue-green alga," Nature, vol. 314, no. 6012, pp. 617-620, 1985. 
[2] S. V. Vassilev, D. Baxter, L. K. Andersen, C. G. Vassileva, and T. J. Morgan, "An overview of the organic and inorganic phase composition of biomass," Fuel, vol. 94, pp. 1-33, 2012.

[3] M. Herrero, J. A. Mendiola, M. Plaza, and E. Ibañez, "Screening for bioactive compounds from algae," in Advanced Biofuels and Bioproducts, pp. 833-872, Springer, New York, NY, USA, 2013.

[4] W. A. J. P. Wijesinghe and Y.-J. Jeon, "Enzyme-assistant extraction (EAE) of bioactive components: a useful approach for recovery of industrially important metabolites from seaweeds: a review," Fitoterapia, vol. 83, no. 1, pp. 6-12, 2012.

[5] X.-H. Xiao, Z.-Q. Yuan, and G.-K. Li, "Preparation of phytosterols and phytol from edible marine algae by microwaveassisted extraction and high-speed counter-current chromatography," Separation and Purification Technology, vol. 104, pp. 284-289, 2013.

[6] E. Conde, A. Moure, and H. Domínguez, "Supercritical $\mathrm{CO}_{2}$ extraction of fatty acids, phenolics and fucoxanthin from freezedried Sargassum muticum," Journal of Applied Phycology, vol. 27, no. 2, pp. 957-964, 2015.

[7] P. du Jardin, "Plant biostimulants: definition, concept, main categories and regulation," Scientia Horticulturae, vol. 196, pp. 3-14, 2015.

[8] B. Hamza and A. Suggars, "Biostimulants: myths and realities," TurfGrass Trends, vol. 8, pp. 6-10, 2001.

[9] B. Ray and M. Lahaye, "Cell-wall polysaccharides from the marine green alga Ulva "rigida" (Ulvales, Chlorophyta). Extraction and chemical composition," Carbohydrate Research, vol. 274, pp. 251-261, 1995.

[10] K. Chojnacka, "Biologically active compounds in seaweed extracts-the prospects for the application," The Open Conference Proceedings Journal, vol. 3, no. 1, pp. 20-28, 2012.

[11] W. Khan, U. P. Rayirath, S. Subramanian et al., "Seaweed extracts as biostimulants of plant growth and development," Journal of Plant Growth Regulation, vol. 28, no. 4, pp. 386-399, 2009.

[12] C. A. Whapham, G. Blunden, T. Jenkins, and S. D. Hankins, "Significance of betaines in the increased chlorophyll content of plants treated with seaweed extract," Journal of Applied Phycology, vol. 5, no. 2, pp. 231-234, 1993.

[13] M. Turan and C. Köse, "Seaweed extracts improve copper uptake of grapevine," Acta Agriculturae Scandinavica Section B: Soil and Plant Science, vol. 54, no. 4, pp. 213-220, 2004.

[14] S. S. Rathore, D. R. Chaudhary, G. N. Boricha et al., "Effect of seaweed extract on the growth, yield and nutrient uptake of soybean (Glycine max) under rainfed conditions," South African Journal of Botany, vol. 75, no. 2, pp. 351-355, 2009.

[15] P. Rayorath, M. N. Jithesh, A. Farid et al., "Rapid bioassays to evaluate the plant growth promoting activity of Ascophyllum nodosum (L.) Le Jol. using a model plant, Arabidopsis thaliana (L.) Heynh," Journal of Applied Phycology, vol. 20, no. 4, pp. 423429, 2008.

[16] S. H. S. Sharma, G. Lyons, C. McRoberts et al., "Biostimulant activity of brown seaweed species from Strangford Lough: compositional analyses of polysaccharides and bioassay of extracts using mung bean (Vigno mungo L.) and pak choi (Brassica rapa chinensis L.)," Journal of Applied Phycology, vol. 24, no. 5, pp. 1081-1091, 2012.

[17] I. Michalak, Ł. Tuhy, and K. Chojnacka, "Seaweed extract by microwave assisted extraction as plant growth biostimulant," Open Chemistry, vol. 13, no. 1, pp. 1183-1195, 2016.

[18] K. S. Sim, A. M. Sri Nurestri, and A. W. Norhanom, "Phenolic content and antioxidant activity of crude and fractionated extracts of Pereskia bleo (Kunth) DC. (Cactaceae)," African Journal of Pharmacy and Pharmacology, vol. 4, no. 5, pp. 193201, 2010.

[19] K. Godlewska, I. Michalak, Ł. Tuhy, and K. Chojnacka, "Plant growth biostimulants based on different methods of seaweed extraction with water," BioMed Research International, vol. 2016, Article ID 5973760, 11 pages, 2016.

[20] D. I. Arnon, "Copper enzymes in isolated chloroplasts. Polyphenoloxidase in Beta vulgarisb," Plant Physiology, vol. 24, no. 1, pp. $1-15,1949$.

[21] H. Narimani, M. M. Rahimi, A. Ahmadikhah, and B. Vaezi, "Study on the effects of foliar spray of micronutrient on yield and yield components of durum wheat," Archives of Applied Science Research, vol. 2, no. 6, pp. 168-176, 2010.

[22] D. T. Westermann, "Nutritional requirements of potatoes," American Journal of Potato Research, vol. 82, no. 4, pp. 301-307, 2005.

[23] P. J. White and P. H. Brown, "Plant nutrition for sustainable development and global health," Annals of Botany, vol. 105, no. 7, pp. 1073-1080, 2010.

[24] S. Hättenschwiler and P. M. Vitousek, "The role of polyphenols in terrestrial ecosystem nutrient cycling," Trends in Ecology and Evolution, vol. 15, no. 6, pp. 238-242, 2000.

[25] I. Ignat, A. Stingu, I. Volf, and V. I. Popa, "Natural bioactive compounds as plant growth regulators," Revista Lucrari Stiintifice-Seria Agronomie, vol. 52, pp. 187-192, 2009.

[26] N. Ruenroengklin, J. Zhong, X. Duan, B. Yang, J. Li, and Y. Jiang, "Effects of various temperatures and $\mathrm{pH}$ values on the extraction yield of phenolics from litchi fruit pericarp tissue and the antioxidant activity of the extracted anthocyanins," International Journal of Molecular Sciences, vol. 9, no. 7, pp. 13331341, 2008.

[27] V.-B. Horincar, G. Parfene, and G. Bahrim, "Evaluation of bioactive compounds in extracts obtained from three Romanian marine algae species," Romanian Biotechnological Letters, vol. 16, no. 6, pp. 71-78, 2011.

[28] M. K. Narasimhan, S. K. Pavithra, V. Krishnan, and M. Chandrasekaran, "In vitro analysis of antioxidant, antimicrobial and antiproliferative activity of Enteromorpha antenna, Enteromorpha linza and Gracilaria corticata extracts," Jundishapur Journal of Natural Pharmaceutical Products, vol. 8, no. 4, pp. 151-159, 2013.

[29] K. Ganesan, K. S. Kumar, and P. V. Subba Rao, "Comparative assessment of antioxidant activity in three edible species of green seaweed, Enteromorpha from Okha, Northwest coast of India," Innovative Food Science and Emerging Technologies, vol. 12, no. 1, pp. 73-78, 2011.

[30] M. L. Cho, H.-S. Lee, I.-J. Kang, M.-H. Won, and S.-G. You, "Antioxidant properties of extract and fractions from Enteromorpha prolifera, a type of green seaweed," Food Chemistry, vol. 127, no. 3, pp. 999-1006, 2011.

[31] I. J. Crouch and J. van Staden, "Evidence for the presence of plant growth regulators in commercial seaweed products," Plant Growth Regulation, vol. 13, no. 1, pp. 21-29, 1993.

[32] I. J. Crouch, R. P. Beckett, and J. van Staden, "Effect of seaweed concentrate on the growth and mineral nutrition of nutrientstressed lettuce," Journal of Applied Phycology, vol. 2, no. 3, pp. 269-272, 1990.

[33] F. Z. Fakihi KachKach, M. El Harchi, and N. El Mtili, "In vitro effect of Ulva rigida extract on the growth of Lepidium sativum and Allium cepa," Maroccan Journal of Biology, vol. 11, pp. 26-31, 2014. 
[34] S. Latique, H. Chernane, M. Mansori, and M. El Kaoua, "Seaweed liquid fertilizer effect on physiological and biochemical parameters of bean plant (Phaesolus vulgaris variety paulista) under hydroponic system," European Scientific Journal, vol. 9, no. 30, pp. 174-191, 2013.

[35] H. E. Osman and O. M. A. Salem, "Effect of seaweed extracts as foliar spray on sunflower yield and oil content," Egyptian Journal of Phycology, vol. 12, pp. 59-72, 2011.

[36] R. A. Khairy, I. M. El-Manawy, and M. A. El-Bramawy, "Use of some Egyptian seaweed as foliar fertilizer for Vicia faba L.," Egyptian Journal of Phycology, vol. 12, pp. 71-88, 2011.

[37] P. J. White and M. R. Broadley, "Biofortification of crops with seven mineral elements often lacking in human diets-iron, zinc, copper, calcium, magnesium, selenium and iodine," New Phytologist, vol. 182, no. 1, pp. 49-84, 2009.

[38] C. E. Harjes, T. R. Rocheford, L. Bai et al., "Natural genetic variation in Lycopene epsilon cyclase tapped for maize biofortification," Science, vol. 319, no. 5861, pp. 330-333, 2008.

[39] H. E. Bouis, C. Hotz, B. McClafferty, J. V. Meenakshi, and W. H. Pfeiffer, "Biofortification: a new tool to reduce micronutrient malnutrition," Food and Nutrition Bulletin, vol. 32, no. 1, pp. S31S40, 2011.

[40] P. Nestel, H. E. Bouis, J. V. Meenakshi, and W. Pfeiffer, "Biofortification of staple food crops," The Journal of Nutrition, vol. 136, no. 4, pp. 1064-1067, 2006. 

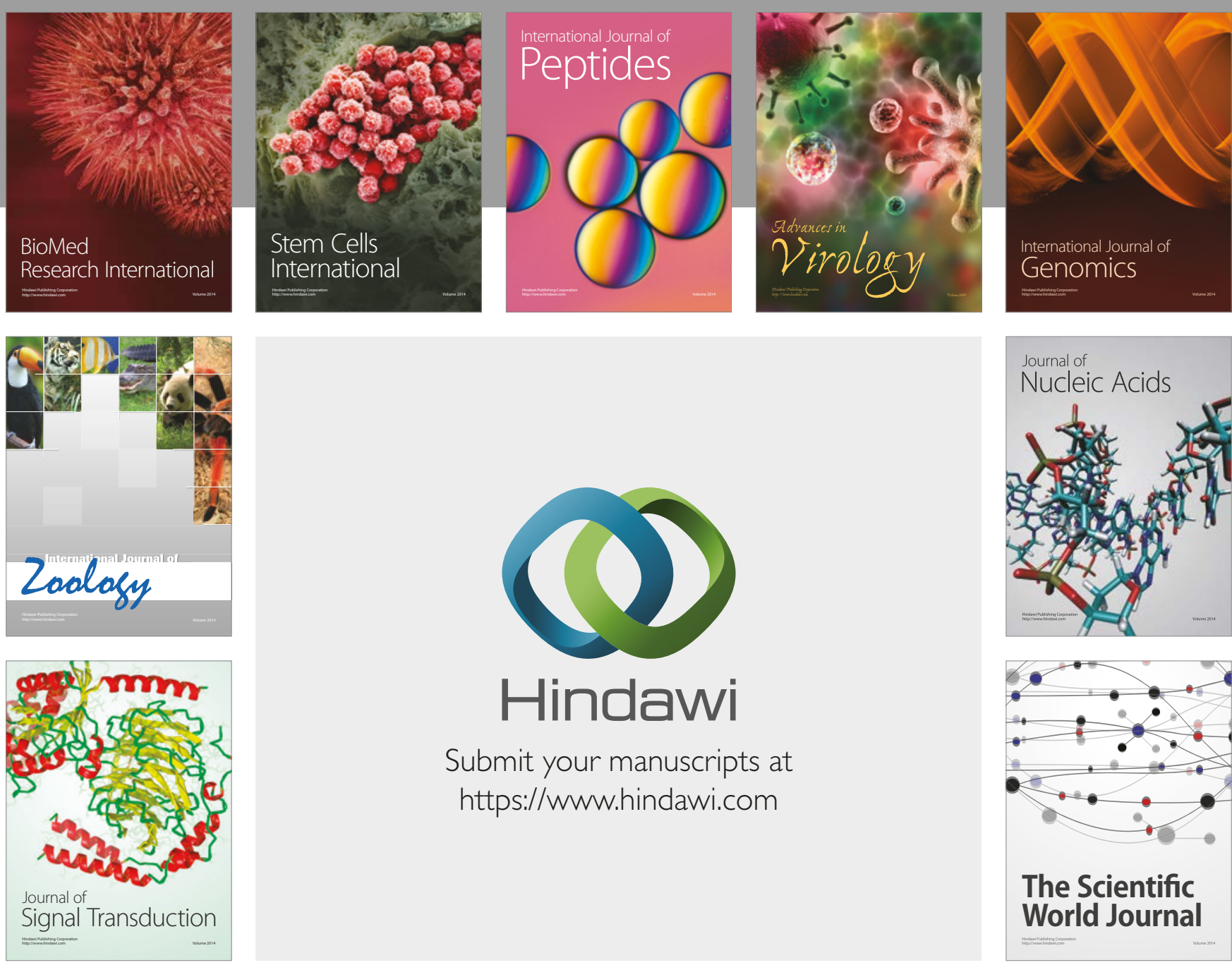

Submit your manuscripts at

https://www.hindawi.com
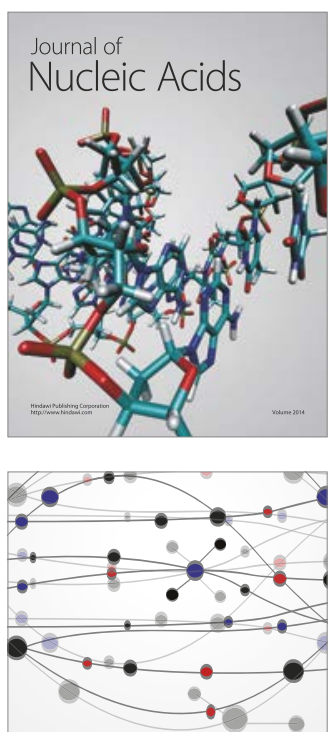

The Scientific World Journal

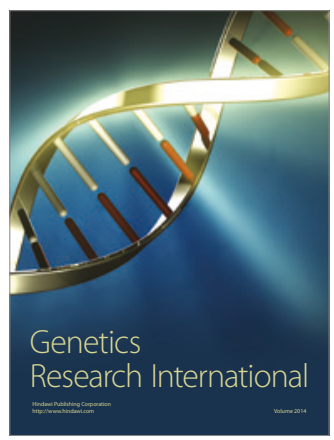

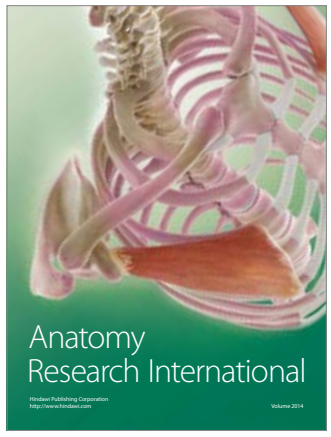

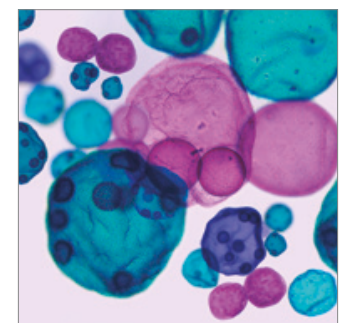

International Journal of Microbiology
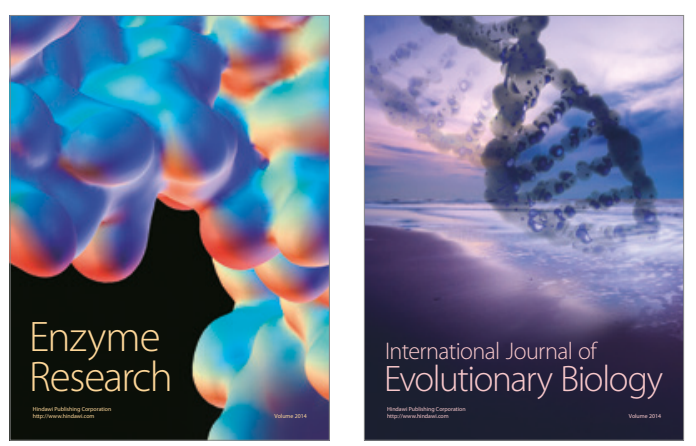
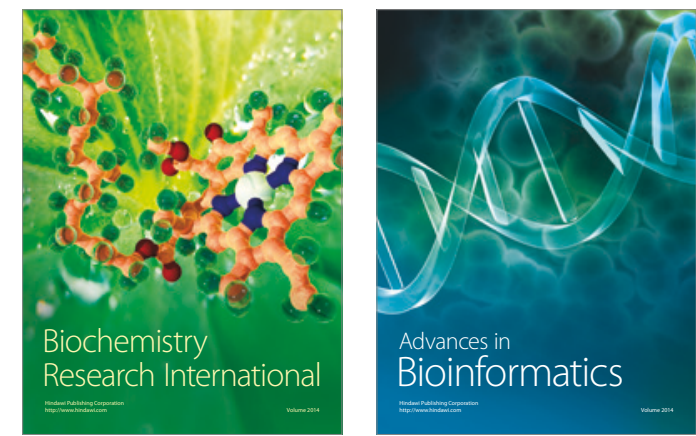

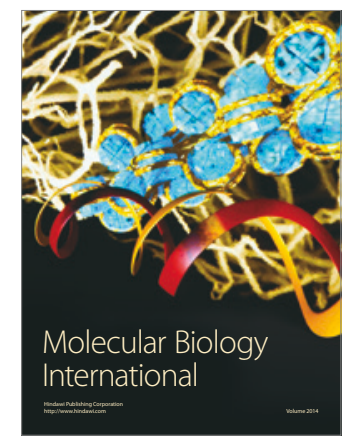

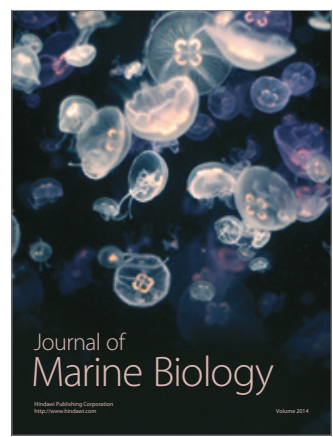

